\title{
A REVIEW OF POTENTILLO TERNATAE - NARDION STRICTAE ALLIANCE
}

\author{
Nikolay I. VELEV ${ }^{1} \&$ Iva I. APOSTOLOVA ${ }^{1}$
}

\begin{abstract}
A classification of the Nardus stricta dominated communities in the Balkan Range is presented. Two associations are identified: Nardetum strictae and Campanulo alpinae - Nardetum strictae nom. nov. The alliance Potentillo ternatae - Nardion strictae is typified and some comments on its distribution range and syntaxonomical affiliation to the higher units are presented. A synopsis is included of all available associations referred to Potentillo ternatae - Nardion strictae.
\end{abstract}

Key words: grasslands, nomen novum, nomenclature, numerical methods, syntaxonomy.

\section{Izvleček}

V članku je predstavljena klasifikacija združb z dominantno vrsto Nardus stricta na Balkanu. Prikazali smo dve asociaciji: Nardetum strictae and Campanulo alpinae - Nardetum strictae nom. nov. Zvezo Potentillo ternatae - Nardion strictae smo tipizirali in predstavili njeno razširjenost in sintaksonomsko uvrstitev v višje enote. Prikazan je sinopsis vseh opisanih asociacij, ki jih uvrščamo v zvezo Potentillo ternatae - Nardion strictae.

Ključne besede: travniki, nomen novum, nomenklatura, numerične metode, sintaksonomija.

\section{INTRODUCTION}

The Nardus-rich communities are wide spread in the Bulgarian mountains. They are almost entirely of secondary origin and cover approximately 50000 ha (Velchev et al. 1989). A significant part of them is presented in the Balkan Range as a result of hundreds of years of extensive stock breeding. The syntaxonomical diversity of the mat-grass communities in the Bulgarian part of the Balkan Range has been studied so far following the dominant approach (see Bondev 1966; Ganchev \& Kochev 1969; Meshinev et al. 2000). The same vegetation type, following the Braun-Blanquet approach, was described for Mt. Pirin (Simon 1958), Mt. Rila (Roussakova 2000) and reported for the Balkan Range, the Rhodopes and Mt. Sredna Gora (Meshinev et al. 2005). The successional changes of Nardus stricta communities in the Central Balkan Range were commented by Velev \& Apostolova (2008). The authors refer communities distributed below the timberline to Nardion strictae Br.-Bl. 1926, and those occupying higher elevations (above the timberline) to Potentillo ternatae - Nardion strictae Simon 1958. Similarly, for the Serbian territory, Kojić et al. $(1998,2004)$ refer the colline mat-grass pastures to Nardion strictae while the mat-grass pastures in the high mountains are considered as part of Potentillo ternatae - Nardion strictae, Fasion orbiculatae Lakušić 1966 and Poion violaceae Horvat 1937.

According to Krahulec (1985) Potentillo ternatae - Nardion strictae should be considered as a Carpathian-Balkanic alliance, characteristic for the vegetation belt above the timberline. On the other hand, the associations recognized so far as being affiliated to this alliance represent an extremely broad variety of ecological and floristic peculiarities.

${ }^{1}$ Department of Phytocoenology and Ecology, Institute of Botany, Bulgarian Academy of Sciences, Acad. G. Bonchev St., bl. 23, 1113 Sofia, Bulgaria, e-mail: nvelev@bio.bas.bg; iva@bio.bas.bg. 
The review of the literature revealed significant differences in authors' concepts regarding relation of the alliance to the higher units (orders and classes). The wealth of information gave us impetus to gather all available in the literature associations and to present the current overview on the Potentillo ternatae - Nardion strictae alliance. The aims of the present study are (i) to identify the syntaxonomy of Nardus stricta communities in the Balkan Range, and (ii) to review the Potentillo ternatae - Nardion strictae alliance.

\section{MATERIAL AND METHODS}

A data set of 336 relevés containing mat-grass were analysed. They are recorded for the Balkan Range (Figure 1) following the dominant approach (Bondev 1966, Ganchev \& Kochev 1969, Meshinev et al. 2000) within an altitudinal range between 1400 and $2200 \mathrm{~m}$.

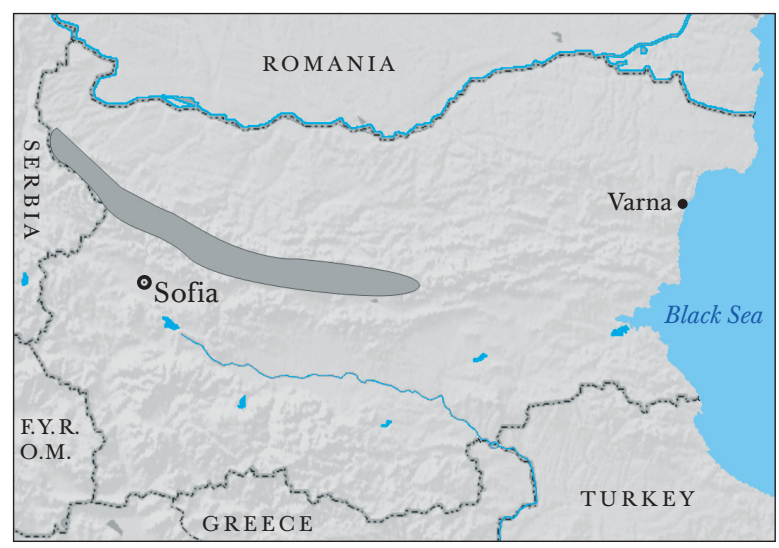

Figure 1: Map of the sampled localities.

Slika 1: Zemljevid proučevanega območja.

Each relevé contains a full list of species excluding the mosses in some descriptions. The sample plots are $100 \mathrm{~m}^{2}$. The original quantitative estimations are transformed to the old BraunBlanquet scale following Meshinev \& Apostolova (2002). The relevés are stored in the TURBOVEG data base (Hennekens \& Schaminèe 2001). They are exported into JUICE software (Tichy 2002) for further analysis. Subsequently unsupervised classification (TWINSPAN - Hill 1979) and supervised classification using the Cocktail method (Bruelheide 1995, 2000) are applied. Two sociological groups (cf. Bruelheide 2000; Chytrý 2007) were identified within the Cocktail method: (1) setting as an initial species Nardus stricta and rep- resenting class Calluno - Ulicetea, and (2) setting as an initial species funcus trifidus and representing class funcetea trifidi. Each group includes five species. The classification of the relevés is based on the presence of at least three of these species. We used the logical operator AND (Bruelheide 1997) to compose formal definitions for the two associations for the Balkan Range.

All available literature is referred to in order to elaborate a full list of associations of Potentillo ternatae - Nardion strictae alliance.

The syntaxonomical interpretation follows the floristic and ecological principles (Braun-Blanquet 1965; Westhoff \& der Maarel 1973; MuellerDombois \& Ellenberg 1974).

The syntaxonomical nomenclature of the revisions is in accordance with the International Code of Phytosociological Nomenclature (Weber et al. 2000) (in the text ICPN).

The nomenclature of the species follows Delipavlov et al. (2003), Kozhuharov (1992), Natcheva \& Ganeva (2005) and Wirth (1995), while the floristic elements are used after Oberdorfer (1994) and Assyov \& Petrova (2006).

\section{RESULTS AND DISCUSSION}

The unsupervised classification of the relevés reveals that the mat-grass communities in the Balkan Range are divided into two distinct groups in relation to altitude and referring to different alliances. A part of the studied relevés is located within the subalpine belt and another part within the alpine belt. Although there are common species presented, the groups are well separated by a number of diagnostic species. The same groups are established as a result of the implementation of supervised classification and the Cocktail method (Bruelheide 1995, 2000) as well. Two associations are clearly identified: Nardetum strictae and Campanulo alpinae - Nardetum strictae (Table 1).

The remaining relevés are spread among other cluster groups and are not considered in the subsequent analysis.

\section{Association Nardetum strictae Grebenščikov 1950}

Sociological group Nardus stricta: Nardus stricta, Festuca rubra, Agrostis capillaris, Hieracium hoppeanum, Verbascum longifolium.

Formal definition for the Balkan Range: Group 
Nardus stricta AND Nardus stricta cover > $25 \%$.

The identified Nardetum strictae association of the Balkan Range is developed at an altitudinal range of 1400-2080 m. It occupies formerly intensive pasturelands, which are currently extensively used. The communities are distributed over all the range of the studied area (Fig. 1). They are localized on ridges or slightly inclined slopes, creating conditions for preservation of the relatively well developed soil layer. The rocks are silicate.

Theassociation was described by Grebenščikov for Mt. Stara Planina (Serbia) (Kojić et al. 1995). It is confirmed for the same locality also by Mišić et al. (1978) and Kojić et al. (1998). Janković (1982) and Kojić et al. (1995, 1998) stated that Nardus stricta dominated pastures (recognized as Nardetum strictae sensu lato) are a complex of many associations with different ecological characteristics. According to Kojić et al. (1998) the complex Nardetum strictae sensu lato is divided into 18 associations, one of which is ass. Nardetum strictae Grebenščikov 1950. This association is treated as a separate syntaxon also by Kojić et al. (2004) and Lakušić et al. (2005). Nevertheless, this association is accepted as having a broad ecological amplitude (Mišić et al. 1978, Kojić et al. 1995) but never interpreted as a synonym of the complex Nardetum strictae sensu lato. Kojić et al. (1995) mentioned that many authors misjudge the described association for the Stara Planina association. According to ICPN rules such associations are pseudonyms and in this case should be considered as Nardetum strictae auct. non Grebenščikov 1950.

Association Nardetum strictae Greb. 1950 ecologically is very close to that described for Romania by Simon (1966) as association Violo declinatae - Nardetum strictae. The difference between these associations is that Viola declinata Waldst. \& Kit. is missing in Nardetum strictae. This species does not occur in Serbia and Bulgaria (see Diklić 1972; Delipavlov 1979; Assyov \& Petrova 2006) where the taxonomically related species Viola dacica Borb. (= V. declinata Waldst. \& Kit. ssp. bulgarica Form.) was recorded.

According to Grigoriu \& Alda (2004) the Violo declinatae - Nardetum strictae association unifies the mat-grass communities in Eastern Europe. Such a statement could be proved by the fact that numerous relevés related to the Violo declinatae - Nardetum strictae association (Simon 1966; Mihăilescu 2001; Grigoriu \& Alda 2004), includ- ing its synonyms (e.g. Nardetum alpigenum austro - carpaticum Borza 1959 and Nardo - Vaccinietum Resm. 1970) do not contain $V$. declinata even in their original records.

\section{Association Campanulo alpinae - Nardetum} strictae (Simon 1958) nom. nov. hoc loco

Nomenclatural type: Simon (1958: Table 8, rel. 3), lectotypus hoc loco designatus

Homotypical synonym: Nardetum alpinum moesiacum Simon 1958 nomen illegitimum (Art. 34a).

Sociological group funcus trifidus: funcus trifidus, Campanula alpina, Festuca airoides, Agrostis rupestris, Sesleria comosa.

Formal definition for the Balkan Range: Group Funcus trifidus AND Nardus stricta cover > $5 \%$.

The association was described by Simon for Mt. Pirin (Simon 1958: 179-180, Table 8). The originally recorded relevés of the association are included in Table 1 (relevés 52-57, and is typified by relevé 54 ). The confirmation of this syntaxon 50 years after its establishment reveals its particular character and does not provide reasons for it to be a nomen dubium (Art. 37); followng the ICPN rules a nomen novum should be given. According to ICPN the new name is typified by the typus of the rejected one. We selected the typus following the recommendations of ICPN where both Campanula alpina and Nardus stricta are presented. Nardus stricta dominates (projection coverage $>25 \%$ ) and remains in the name (Art. 3k, 10b, 29b). The species Campanula alpina is well presented in the relevés under this association simultaneously from Mt. Pirin and Mt. Balkan (see Table 1). This species indicates the alpine character of the association and is mentioned as diagnostic for alliance Seslerion comosae by Horvat, Pawlowski \& Wałas (1938), Simon (1958) and Horvat et al. (1974). According to Cheshmedzhiev (2003) in Bulgaria only Campanula alpina Jacq. ssp. orbelica (Pančič) Urum. is presented within an altitudinal range from 1700 to $2900 \mathrm{~m}$ a.s.l.

In the studied area the association is distributed occasionally within the alpine belt between 1950 and 2200 m altitiude. The communities are localized mainly on ridges or highly inclined slopes where the soils are slightly eroded. The rocks are silicate. Considering the floristic composition of the association (see Table 1) we definitely support Simon's (1958) opinion that this type of vegetation is derived from Agrostidi - Seslerietum comosae Horvat, Pawlowski \& Wałas 
1938, or from Seslerietalia comosae meadows in the way of pasture digression.

Simon (1958) includes the association in Potentillo ternatae - Nardion strictae (Nardetalia, Nardo-Callunetea). At the same time, Simon (1958 in Table 8) points out diagnostic species for Seslerion comosae, Poion violaceae and Seslerietalia comosae. The main difference between Seslerion comosae and Potentillo ternatae - Nardion strictae after the cited reference is high abundance of $\mathcal{N a r}$ dus stricta. The species Potentilla ternata is pointed out in this source as diagnostic also for Seslerietalia comosae. We do not support the decision taken by the author regarding association affiliation to higher syntaxa, because of lacking in diagnostic species both for the order and the class (see Table 1, rel. 52-57). Following the rules of floristic resemblance (Westhoff \& van der Maarel 1973), and taking into account the presence of several diagnostic species (Table 1), we refer the Campanulo alpinae - Nardetum strictae association to Seslerion comosae alliance (Seslerietalia comosae, funcetea trifidi). The dominant position of Nardus stricta in the communities is not sufficient reason for relating an association to Nardetalia strictae and Calluno Ulicetea. In maintainance of such an opinion many authors (Boşcaiu 1971; Coldea 1990; Krahulec et al. 1996; Roussakova 2000; Devillers \& Devillers-Terschuren 2001; Rodwell et al. 2002; Chytrý \& Tichý 2003; Koči 2007, etc.) refer the mat-grass communities which contain Arctic-Alpine species to the funcetea trifidi class.

\section{Alliance Potentillo ternatae - Nardion strictae Simon 1958}

Nomenclatural type: Violo declinatae - Nardetum strictae Simon 1966, [Simon (1966): p. 260, Table 2], neotypus hoc loco designatus.

This alliance is described by Simon (1958) from Mt. Pirin (Bulgaria). It is established by a single association - Nardetum alpinum moesiacum Simon 1958, which shares the same diagnostic species. According to Def. VIII (ICPN) this association should be considered as holotypus, being the only one described for the alliance. In this particular case it is not applicable because the association belongs to Seslerion comosae as was already pointed out (see Table 1). As a neotypus we suggest Violo declinatae - Nardetum strictae association described from Mt. Bihar (Romania). Simon (1966) did not point out its affiliation to higher units when he published the association. Later on, many Romanian authors (Coldea 1987;
Ivan et al. 1993; Sanda et al. 1997; Mihăilescu 2001; Pop et al. 2002; Niculescu 2004; Grigoriu \& Alda 2004; Sarbu et al. 2004, etc.) included the association within Potentillo ternatae - Nardion strictae.

Simon (1958) refers Potentillo ternatae - Nardion strictae to Nardo - Callunetea, and many other researchers follow this concept, as for example Horvat et al. (1974), Dihoru (1975), Mišić et al. (1978), Pop et al. (1988, 2002), Sanda et al. (1997), Kojić et al. (1997, 1998, 2004), Mihăilescu (2001), Grigoriu \& Alda (2004), Niculescu (2004), Sarbu et al. (2004). Some authors, however, refer it to Funcetea trifidi (cf. Boşcaiu 1971; Coldea 1990; Roussakova 2000; Devillers \& Devillers-Terschuren 2001; Rodwell et al. 2002; Chifu et al. 2006). The problem with the syntaxonomic position of the alliance comes after its distribution close to the alpine belt and thus containing numerous alpine species, such as Agrosris rupestris All., Alopecurus gerardii Vill., Dianthus microlepis Boiss, Euphrasia minima Jacq. ex DC., Festuca riloensis (Hack. ex Hajek) Markgr.-Dannb., Juncus trifidus L., Scleranthus neglectus Rochel ex Baumg., Sesleria comosa Velen. etc (see Table 1). Particularly in Bulgaria the alpine belt is situated between 2400-2925m and very rarely, depending on the local climatic peculiarities, could start from 2000 m altitude and even lower (Velchev 1984, 2002; Bondev 1991). Simon (1958) describes the alliance at the range of $2100-2400 \mathrm{~m}$ a.s.l. and the relevés contain species from different altitudinal belts. The species composition causes ambiguous interpretation of the alliance by different authors. Sarbu et al. (2004) report Potentillo ternatae - Nardion strictae at 1450-1900 m altitude for Romania. They describe it as „acidic oligotrophic subalpine pastures". In Ukraine it occupies altitudes of 1200-2061 m (Malinovsky \& Kricsfalusy 2000; Prots et al. 2008). Rodwell et al. (2002) determine Potentillo ternatae - Nardion strictae as „Mat-grass swards of the alpine belt in the mountains of the eastern Balkans".

The information included in Table 2 reveals relatively broad altitudinal range (500-2400 m) of the described associations within the Potentillo ternatae - Nardion strictae alliance. In fact, associations from different vegetation belts are related to the same alliance and thus combine ecologically different habitats. This contradicts to the BraunBlanquet statement that the alliance unifies "the most closely related associations" (Braun-Blanquet 1965: 363). 
The following 22 associations are reffered to Potentillo ternatae - Nardion strictae:

In Romania: Nardetum strictae subalpinum Domin 1931, Krajina 1933; Campanulo serratae - Festucetum ovinae (Morariu 1942) Coldea 1987; Festucetum ovinae Morariu 1943; Nardo - Callunetum vulgaris Šmarda 1953, Hrynnc. 1959, Csűrös 1964; Poëtum mediae Csűrös et al. 1956; Scorzonero roseae - Festucetum nigricantis (Puşc. et al. 1956) Coldea 1987; Nardetum alpigenum austro - carpaticum Borza 1959; Festuco - Nardetum strictae montanum Csűrös \& Resm. 1960; Potentillo - Festucetum ovinae Resm. (1965) 1969, 1970; Agrosteto - Callunetum vulgaris Resm. \& Csűrös 1966; Violo declinatae - Nardetum strictae Simon 1966; Campanulo abietunae - Nardo - Festucetum commutatae Boşcaiu 1971; Antennario - Festucetum sudeticae Dihoru 1975; Carici - Nardetum strictae (Resm. 1984) Resm. \& Pop 1986; Hieracio pilosellae - Nardetum strictae Pop et al. 1988 (Resmeriță \& Csűrös 1966; Boşcaiu 1971; Dihoru 1975; Coldea 1987, 1990; Coldea \& Pop 1988; Pop et al. 1988; Ivan et al. 1993; Sanda et al. 1997; Mihăilescu 2001; Pop et al. 2002; Niculescu 2004; Grigoriu \& Alda 2004; Chifu et al. 2006).

In former Yugoslavia: Nardetum strictae Greb. 1950; Trifolio pallescens - Nardetum strictae Blečić \& Tatić 1964; Hygronardetum strictae Puşc.-Soroc. 1965; Succiso - Nardetum strictae Stanković-Tomić 1969; Festuco halleri - Nardetum strictae Rajev. 1974; Festuco fallaci - Nardetum strictae Rajev. 1974; Helianthemo - Nardetum strictae Rajev. 1974; Festuco nigrescenti - Nardetum strictae Rexh. \& Ranđ. 1980; Festuco - Nardetum strictae subalpinum Rexh. \& Rand. 1980; Carici oederi - Nardetum strictae Petk. 1981; Ophioslosso - Nardetum strictae Gajić 1989 (Horvat et al. 1974; Mišić et al. 1978; Kojić et al. 1998, 2004).

In Bulgaria: Nardetum strictae Greb. 1950; Carici - Festucetum microphyllae Roussakova 2000 (Roussakova 2000; Velev \& Apostolova 2008).

In Ukraine: Soldanello - Nardetum Malinovsky \& Kricsfalusy 2000 (Malinovsky \& Kricsfalusy 2000).

According to some authors, several of the associations listed above are referred to other alliances, as for example:

Nardetum strictae Greb. 1950, Hygronardetum strictae Puşc.-Soroc. 1965 to the Nardion strictae alliance (Kojić et al. 1998; Puzović et al. 2006; Obratov-Petkovic et al. 2007);

Nardetum strictae Greb. 1950 to the Poion violaceae alliance (Kojić et al. 2004);
Antennario - Festucetum sudeticae Dihoru 1975 to the Caricion curvulae Br.-Bl. 1925 alliance (Sanda 1997);

Nardo - Callunetum vulgaris Šmarda 1953, Hrynnc. 1959, Csűrös 1964 to the Genistion Böch. 1943 alliance (Sanda 1997);

Violo declinatae - Nardetum strictae Simon 1966 to the Nardion strictae alliance (Chifu et al. 2006).

In the literature as diagnostic for Potentillo ternatae - Nardion strictae are listed the following species: Agrostis rupestris All., Alchemilla flabellata Buser, A. glaucescens Wallr., A. monticola Opiz, A. xanthochlora Rothm., Antennaria dioica (L.) Gaertner, Anthoxanthum alpinum Á.Löve \& D.Löve, Bellardiochloa violacea (Bell.) Chiov., Botrychium lunaria (L.) Sw., Bruckenthalia spiculifolia Rchb., Campanula excisa Presl., C. kladniana (Schur) Witasek, C. patula L. ssp. abietina (Griseb.) Somonkai, C. rotundifolia L.,C. serrata (Kit.) Hendrych, Carex bulgarica (Domin) Lazare, Carlina acaulis L., Centaurea nervosa Willd., Cerastum fontanum Baumg., Crocus neapolitanus Mordant \& Loisel., Diphasium alpinum (L.) Rothm., Euphrasia minima Lam. \& DC., Festuca airoides Lam., F. nigrescens Lam., F. ovina L., Gentiana acaulis L., Gentianella lutescens (Velen.) J. Holub, Geum montanum L., Helictotrichon versicolor (Vill.) Pilger., Hieracium alpinum L., H. aurantiacum L., H. hoppeanum Schultes, H. lactucella Wallr., Homogyne alpina (L.) Cass., Hypericum maculatum Crantz, Hypochaeris uniflora Vill., Leontodon rilaensis Hayek, Ligusticum mutellina (L.) Crantz, Luzula sudetica (Willd.) DC., Nardus stricta L., Phleum alpinum L., Plantago atrata Hoppe, $P$. gentianoides Sibth. \& Sm., Poa alpina L., P. media Schur, Potentilla aurea L., P. erecta (L.) Rausch., P. ternata C. Koch., Primula elatior (L.) Hill., Pseudorchis albida (L.) A. \& D. Lőve, Scorzonera purpurea L. ssp. rosea (Waldst. \& Kit.) Nym., Solidago virgaurea L. ssp alpestris (W. \& K.) Gaud., Thesium alpinum L., Thlaspi dacicum Heuffel, Thymus alpestris Tausch, T. pulegioides L., T. vandasii Velen., Veronica alpina L., V. officinalis L., Viola canina L., V. dacica Borbas and V. declinata Waldst. \& Kit. (Simon 1958; Boşcaiu 1971; Dihoru 1975; Coldea 1987, 1990; Coldea \& Pop 1988; Sanda et al. 1988, 1997; Ivan et al. 1993; Roussakova 2000; Malinovsky \& Kricsfalusy 2000; Mihăilescu 2001; Niculescu 2004; Grigoriu \& Alda 2004; Sarbu et al. 2004; Petrík et al. 2005; Chifu et al. 2006).

Some species, as for example Homogyne alpina, Festuca airoides, Nardus stricta, Poa media, Po- 
tentilla ternata, are pointed out also as diagnostic for Seslerietalia comosae or funcetea trifidi (Simon 1958; Mucina et al. 1990; Roussakova 2000; Chytrý \& Tichý 2003; Koči 2007). Horvat et al. (1937) point out Potentilla ternata as diagnostic for the alpine vegetation included in Caricetalia curvulae Br.-Bl. 1926. At the same time, species as Veronica officinalis, Cerastum fontanum, Thymus pulegioides, Hieracium hoppeanum and Potentilla erecta have broad distribution and practically are not considered characteristic for the sub-alpine and alpine vegetation.

The proximity of alpine vegetation much influences Potentillo ternatae - Nardion strictae. Floristic-geographical analysis of the diagnostic species shows that $49 \%$ have Alpine and ArcticAlpine distribution. Another $18 \%$ of the species represent the sub-Atlantic floristic element. Carpathian-Balkanic flora is presented by $14 \%$ of diagnostic species and could be an argument for distinction of the alliance. The list of diagnostic species reveals significant resemblance between Potentillo ternatae - Nardion strictae and Nardion strictae.

Mention should also be made of Nardo strictae - Agrostion tenuis Sillinger 1933 which is presented in the Krkonoše and the West Carpathian Mts (Krahulec 1990; Krahulec et al. 1996). The species composition of the relevés from the Krkonoše Mts is similar to our data. It could be suggested that one large alliance (Nardion ?) actually includes geographically differentiated suballiances like Potentillo ternatae - Nardion strictae and Nardo strictae - Agrostion tenuis. But large data set analysis is needed to prove this hypothesis.

\section{CONCLUSIONS}

The mat-grass communities in Bulgaria, as in many European countries, are most often a sequence of long-time intensive grazing and trampling. The pastures are distributed in the mountains, mostly above the timberline and occur in different altitudinal vegetation belts. In the alpine vegetation, the communities characterized by significant Nardus stricta abundance are related to funcetea trifidi class, which is supported by the presence of many preserved diagnostic species (e.g. Juncus trifidus, Veronica bellidioides, Festuca airoides, Campanula alpina, Agrostis rupestris). At lower altitudes, in the subalpine belt, the grazing has been more intensive. These ter- ritories are covered by huge mountain pastures, quite uniform due to the strong dominance of the mat-grass. In the Balkan Range these communities are referred to Potentillo ternatae - Nardion strictae. We typified the Potentillo ternatae - Nardion strictae alliance by Violo declinatae - Nardetum strictae association. The Potentillo ternatae - Nardion strictae vegetation includes many character species (e.g. Potentilla erecta, Agrostis capillaris, Hypericum maculatum, Festuca rubra) for Calluno - Ulicetea and should be subordinated to this class. The high abundance of Nardus stricta in a vegetation type does not necessarily refer this vegetation to Calluno - Ulicetea. The mat-grass pastures developed on places of former funcetea trifidi syntaxa remain syntaxonomically in the same class. It might be predicted that a decrease in the grazing and trampling intensity, which is ongoing currently at many places in the high mountains, will reduce the mat-grass abundance and will result in demutation to the primary vegetation communities.

\section{SYNTAXONOMICAL SYNOPSIS:}

Class funcetea trifidi Hadač in Klika \& Hadač 1944 [Syn.: Caricetea curvulae Br.-Bl. 1948)]

Order Seslerietalia comosae (Simon 1958) Lakušić 1966

Alliance Seslerion comosae Horvat 1935 em. Lakušić 1966

Ass. Campanulo alpinae - Nardetum strictae (Simon 1958) nom. nov.

Class Calluno-Ulicetea Br.-Bl. \& Tüxen ex Klika \& Hadač 1944 [Syn.: Nardo - Callunetea Preising 1949]

Order Nardetalia strictae Preising 1949

Alliance Potentillo ternatae - Nardion strictae Simon 1958

Ass. Nardetum strictae subalpinum Domin 1931, Krajina 1933 nom. illeg. (Art. 34a) [Syn.: Nardetum strictae montanum Sillinger 1933] Ass. Nardetum strictae Greb. 1950

Ass. Poëtum mediae Csűrös et al. 1956

Ass. Nardo - Callunetum vulgaris Šmarda 1953, Hrynnc. 1959, Csűrös 1964 [Syn.: Vaccinio - Callunetum vulgaris Bük. 1942; Agrosteto Callunetum vulgaris Resm. \& Csűrös 1966; Arnica montana - Calluna vulgaris Ghişa et al. 1970; Festuceto rubrae - Callunetum vulgaris Resm. 1970] 
Ass. Trifolio pallescens - Nardetum strictae Blečić \& Tatić 1964

Ass. Hygronardetum strictae Puşc.-Soroc. 1965 nom. illeg. (Art. 34a)

Ass. Violo declinatae - Nardetum strictae Simon 1966 [Syn.: Nardetum strictae alpinum Borza 1934 (Art. 34a) p. p.; Nardetum strictae alpinum Ghişa 1940 (Art. 34a) p. p.; Nardetum strictae alpinum Csűrös 1955 (Art. 34a) p. p.; Nardetum strictae alpinum Puşcaru et al. 1956 (Art. 34a); Nardetum alpigenum austro - carpaticum Borza 1959 (Art. 34a); Nardetum strictae subalpinum Buia et al. 1962 (Art. 34a); Nardetum strictae alpinum Buia et al. 1962 (Art. 34a); Nardetum strictae alpinum Buia 1963 (Art. 34a) p. p.; Nardetum strictae montanum Resmeriță \& Csűrös 1963 nom. illeg. (Art. 34a); Agrosteto-Festucetum rubrae montanum nardosum Resm. \& Csürös 1966 nom. illeg. (Art. 34a); Nardetum strictae alpinum Beldie 1967 (Art. 34a) p. p.; Nardo - Vaccinietum Resm. 1970; Nardo-Festucetum tenuifoliae Buiculescu 1971; Festuco rubrae - Agrostetum capillaris Horvat 1951 var. Nardus stricta Danciu 1974; Nardo-Festucetum tenuifoliae Buiculescu 1971; Festuco rubrae - Agrostetum capillaris Horvat 1951 subass. nardetosum strictae Pop 1976]

Ass. Succiso - Nardetum strictae StankovićTomić 1969

Ass. Festuco fallaci - Nardetum strictae Rajev. 1974

Ass. Festuco halleri - Nardetum strictae Rajev. 1974

Ass. Helianthemo - Nardetum strictae Rajev. 1974

Ass. Antennario - Festucetum sudeticae Dihoru 1975 [Syn.: Festucetum supinae Domin 1933; Festucetum supinae subalpinum Sillinger 1933 p. p.; Festuca supina - Nardus stricta Şerbănescu 1939; Festuca supina Puşcaru et al. 1959; Festuca supina - Deschampsia flexuosa - Vaccinium myrtillus Puşcaru et al. 1959; Festuca supina - Festuca rubra fallax Puşcaru et al. 1959; Festucetum supinae Vicol et al. 1971; Potentillo chrysocraspedaeFestucetum airoidis Boșcaiu 1971; Potentillo ternatae - Festucetum supinae Boşcaiu 1971]

Ass. Festuco nigrescenti - Nardetum strictae Rexh. \& Rand. 1980

Ass. Festuco - Nardetum strictae subalpinum Rexh. \& Rand. 1980 nom. illeg. (Art. 34a)

Ass. Carici oederi - Nardetum strictae Petk. 1981
Ass. Carici - Nardetum strictae (Resm. 1984) Resm. \& Pop 1986 [Syn.: Hygronardetum strictae Borza 1934, Hygronardetum strictae Puşc. et al. 1956; Hygronardetum subalpinum Resm. \& Csűrös (1960) 1963; Hygronardetum strictae alpinum Buia et al. 1962, Hygronardetum strictae alpinum Resm. \& Csűrös 1963; Hygronardetum montanum Resm. \& Csűrös 1963, Hygronardetum strictae montanum Buia 1963]

Ass. Campanulo serratae - Festucetum ovinae (Morariu 1943) Coldea 1987 [Syn.: Festucetum ovinae Morariu 1943; Festuceto ovinae - Potentilletum aureae Resm. 1965; Potentillo - Festucetum ovinae Resm. 1965, 1986; Potentillo aureae - Festucetum ovinae Resm. 1969, 1970, Resm. \& Pop 1984; Violo declinatae - Nardetum strictae Simon 1966 subass. festucetosum ovinae (Morariu 1943) Chifu et al. 2006]

Ass. Scorzonero roseae - Festucetum nigricantis (Puşc. et al. 1956) Coldea 1987 [Syn.: Festucetum rubrae fallax Puşc. et al. 1956; Nardo - Festucetum rubrae fallax Puşc. et al. 1959; Festuca supina - Festuca rubra Puşc. et al. 1959; Festucetum rubrae montanum Csűrös \& Resm. 1960; Festucetum rubrae subalpinum siliciculum Csűrös \& Resm. 1960; Festuco - Nardetum strictae montanum Csűrös \& Resm. 1960; Festuco rubrae - Nardetum Csűrös \& Resm. 1960; Festuco - Alchemilletum vulgaris Csűrös \& Resm. 1960; Campanulo abietinae - Nardo - Festucetum commutatae Boşcaiu 1971 nom. nud. (Art. 2a)]

Ass. Hieracio polosellae - Nardetum strictae Pop et al. 1988 pro syn., nom. nud. (Art. 2b, 3a, Recomm. 46f) [Syn.: Xeronardetum Soó 1931; Xeronardetum montanum Resm. \& Csűrös 1963]

Ass. Ophioslosso - Nardetum strictae Gajić 1989

Ass. Carici - Festucetum microphyllae Roussakova 2000

Ass. Soldanello-Nardetum Malinovsky \& Kricsfalusy 2000

\section{ACKNOWLEDGEMENTS}

We thank the two anonymous reviewers for the helpful comments and critical remarks on a previous version of the manuscript. 


\section{REFERENCES}

Assyov, B. \& Petrova, A. (eds): 2006. Conspectus of the Bulgarian Vascular Flora. Distribution Maps and Floristic Elements. Ed. 3. BBF, Sofia, $453 \mathrm{pp}$.

Beldie, A. 1967: Flora and vegetation of Bucegi Mountain. Acad. Press, Bucharest, 578 pp. (in Romanian).

Bondev, I. 1966: Die Hochgebirgs-Pflanzendecke des Berkovischen und Ćiprovschen Gebirges. Izv. Bot. Inst. (Sofia), 16: 79-169 (in Bulgarian).

Bondev, I. 1991: The Vegetation of Bulgaria. Map 1: 600000 with explanatory text. St. Kliment Ohridski Univ. Press, Sofia, 184 pp. (in Bulgarian).

Borza, A. 1959: Flora and vegetation of Sebeşuliu valley. Acad. Press, Bucharest, 326 pp. (in Romanian).

Boşcaiu, N. 1971: Flora and Vegetation of Tarcu, Godeanu and Cerna Mountains. Acad. Press, Bucharest, 494 pp. (in Romanian).

Boşcaiu, N. \& Täuber, F. 1985: Die zönologischen Verhäiltnisse der dazischen und dazisch-balkanischen Arten aus dem rumäinischen Karpatenraum. Vegetatio 59: 185-192.

Braun-Blanquet, J. 1965: Plant Sociology. The Study of Plant Communities. Hafner Publishing Company, New York, London, 439 pp.

Bruelheide, H. 1995: Die Grünlandgesellschaften des Harzes und ihre Standortsbedingungen. Mit einem Beitrag zum Gliederungssystem auf der Basis von statistisch ermittelten Artengruppen. Dissertationes Botanicae 244, 338 pp.

Bruelheide, H. 1997: Using formal logic to classify vegetation. Folia Geobot. Phytotax. 32: 41-46.

Bruelheide, H. 2000: A new measure of fidelity and its application to defining species groups. Journal of Vegetation Science 11: 167-178.

Buia, A. 1963: Les Associations á Nardus stricta L. De La R. P. R. Rev. de Biol. 8(2): 119-138.

Cheshmedzhiev, I. 2003: Family Campanulaceae. In: Delipavlov, D., Cheshmedzhiev, I., Popova, M., Terziyski, D. \& Kovachev, I.: Handbook to the vascular plants in Bulgaria. Acad. Press of Agricult. Univ., Plovdiv, 370-376 pp. (in Bulgarian).

Chifu, T., Mânzu, C. \& Zamfirescu, O. 2006: Flora and vegetation of Moldova: Romania. Vol. 2: Vegetation. Univ. Press "Al. I. Cuza", 700 pp. (in Romanian).
Chytrý, M. 2007: Project Vegetation of the Czech Republic: Preface and summary of methods. In: Chytrý, M. (ed.): Grassland and Heathland Vegetation. Vegetation of the Czech Republic. Vol. 1, Academia, Prague, 35-52 pp.

Chytrý, M. \& Tichý, L. 2003: Diagnostic, constant and dominant species of vegetation classes and alliances of the Czech Republic: a statistical revision. Folia Fac. Sci. Nat. Univ. Masaryk. Brun., Biol. 108: 1-231.

Coldea, G. 1987: Contributions to the syntaxonomic and ecologic study of some acidophilous - mezophill meadows in the subalpine belt of the Romanian Carpathians. Contrib. Bot. 27: 121-131 (in Romanian).

Coldea, G. 1990: The Rodna Mountains. A geobotanical study. Edit. Acad. Press, Bucharest, 183 pp. (in Romanian).

Coldea, G. \& Pop, A. 1988: Phytocoenological researches in the Cozia Mountains. Contrib. Bot. 28: 51-65 (in Romanian).

Csűrös, Ş. \& Resmeriță, I. 1960: Study of Festuca rubra L. pastures in Transylvania. Contrib. Bot. 2: 149-174 (in Romanian).

Delipavlov, D. 1979: Violaceae Batsch. In: Jordanov, D. (ed.), Fl. Reipubl. Popularis Bulgaricae. Vol. 7, In Aedibus Acad. Sci. Bulgaricae, Serdicae, 338-395 pp. (in Bulgarian).

Delipavlov, D., Cheshmedzhiev, I., Popova, M., Terziyski, D. \& Kovachev, I. 2003: Handbook to the vascular plants in Bulgaria. Acad. Press of Agricult. Univ., Plovdiv, 591 pp. (in Bulgarian).

Devillers, P. \& Devillers-Terschuren, J. 2001: Application and development of the Palaearctic habitat classification in the course of the setting up of the Emerald Project - Croatia. Strasbourg, $147 \mathrm{pp}$.

Dihoru, G. 1975: The vegetal cover of the Siriu Mountain. Edit. Acad. Press, Bucharest, 216 pp. (in Romanian).

Diklić, N. 1972: Violaceae De Cand. In: Josifović, M. (ed.): Flora of Serbia. Vol. 3, Acad. Press, Belgrade, 128-164 pp. (in Serbian).

Donitãa, N., Popescu, A., Paucã-Comãnescu, M., Mihãilescu, S. \& Biriş, I. A. 2005: Habitats of Romania. Tehnicã Silvicã Press, Bucharest, 496 pp. (in Romanian).

Ganchev, S. \& Kochev, H. 1969: Investigations into the changes of the wire-bent coenoses ( $\mathrm{Nar}$ deta strictae) depending on the various methods of influence in the Etropole Balkan. Izv. Bot. Inst. (Sofia) 19: 63-75 (in Bulgarian). 
Gergely, I. 1969: The mesophile pastures in the northern part of Trăscău Mountain. Contrib. Bot. 9: 191-209 (in Romanian).

Ghişa, E., Resmeriță, I. \& Spârches, Z. 1970: Contribution to the study of Calluna vegetation in Apuseni Mountain. Contrib. Bot. 10: 183-190 (in Romanian).

Grigoriu, A. \& Alda, N. 2004: Nardus stricta L. meadow phytocoenology, synecology and chorology in the Timis river basin. Contrib. Bot. 39: 95-104.

Hennekens, S. \& Schaminèe, J.H.J. 2001: TURBOVEG, a comprehensive data base management system for vegetation data. J. Veg. Sci. 12: $589-591$.

Hill, M.O. 1979: TWINSPAN. A FORTRAN program for arranging multivariate data in an ordered two-way table by classification of individuals and attributes. Ecology \& Systematics, Cornell University, Ithaca, NY, $45 \mathrm{pp}$.

Horvat, I., Pawlowski, B. \& Walas, J. 1937: Phytosoziologische studien über die hochgebirgsvegetation der Rila Planina in Bulgarien. Bull. Acad. Polon. Sci. Lettres Clas. Mat. Nat. B 1: 159-197.

Horvat, I., Glavač, V. \& Ellenberg, H. 1974: Vegetation Südosteuropas. G. Fischer Verlag, Stuttgart, $766 \mathrm{pp}$.

Ivan, D., Donita, N., Coldea, G., Sanda, V., Popescu, A., Chifu, T., Boscaiu, N., Mititelu, D. \& Pauca-Comanescu, M. 1993: Vegetation potentielle de la Roumanie. Braun-Blanquetia 9: 1-79.

Janković, M. 1982: Contribution to the study of the vegetation of the Šarplanina mountain with particular reference to some conspicuous relict plant species. - Glasn. Inst. za botan. i botan. bašte Univ. u Bgd. 15 (1-3): 75-129 (in Serbian).

Koči, M. 2007: Alpine grasslands on base-poor soils. - In: Chytrý, M. (ed.), Grassland and Heathland Vegetation. Vegetation of the Czech Republic. Vol. 1, Academia, Prague, 76-83 pp.

Kojić, M., Mrfat-Vukelić, S., Dajić, Z., Ajder, S. \& Ostojić, S. 1995: Spreading, main characteristics and types of further research of the plant communities Nardetum strictae sensu lato in Serbia. Glasn. Inst. za botan. i botan. bašte Univ. u Bgd. 28: 115-136 (in Serbian).

Kojić, M., Popović, R. \& Karadžić, B. 1997: Vascular plants of Serbia as indicators of plant communities. Institut za biološka istraživanja "Siniša Stanković", Belgrade, 160 pp. (in Serbian).
Kojić, M., Popović, R. \& Karadžić, B. 1998: A syntaxonomic Review of Vegetation in Serbia. Belgrade, 218 pp. (in Serbian).

Kojić, M., Mrfat-Vukelić, S., Dajić, Z.\& DjordjevićMilosević, S. 2004: Meadows and pastures of Serbia. Agricultural research institute Serbia, Belgrade, 89 pp. (in Serbian).

Kozhuharov, S., (ed.). 1992: Field Guide to the Vascular Plants in Bulgaria. Naouka \& Izkoustvo, Sofia, 788 pp. (in Bulgarian).

Krahulec, F. 1985: The chorologic pattern of European Nardus - rich communities. Vegetatio 59: 119-123.

Krahulec, F. 1990: Nardo - Agrostion tenuis communities in the Krkonoše and West Carpathians Mts. Folia Geobotanica et Phytotaxonomica 25: 337-347.

Krahulec, F., Blažková, D., Balátova-Tuláčková, E., Štursa, J., Pecháčková, S. \& Fabšičová, M. 1996: Grasslands of the Krkonoše Mountains: Plant communities and their dynamics. Opera Concortica 33: 3-250 (in Czech).

Lakušić, D., Blaženčić, J., Randjelović, V., Butorac, B., Vukojičić, S., Zlatković, B., Jovanović, S., Šinžar-Sekulić, J., Žukovec, D., Ćalić, I. \& Pavićević, D. 2005: Habitats of Serbia. Manual with descriptions and basic data. Glasn. Inst. za botan. i botan. bašte Univ. u Beogradu, 684 pp. (in Serbian).

Malinovsky, K. \& Kricsfalusy, V. 2000: HighMountain Vegetation. In: Solomakha, V. (ed.): Vegetation of Ukraine. Vol. 1, Kiev, 230 pp. (in Ukrainian).

Meshinev, T., Apostolova, I., Kachaunova, E., Velchev, V. \& Bondev, I. 2000: Flora and plant communities. In: Popov, A. \& Meshinev, T. (eds): High-Mountain Treeless Zone of the Central Balkan National Park. Biological Diversity and Problems of its Conservation. BSBCP, Sofia, 337 pp.

Meshinev, T. \& Apostolova, I. 2002: Transformation of quantitative estimates from the phytocoenological relevès based on the dominance approach according to the combined scale of Braun-Blanquet. Phytol. Balcan. 8(3): 347-352.

Meshinev, T., Apostolova, I., Georgiev, V., Dimitrov, V., Petrova, A. \& Veen, P. 2005: Grasslands of Bulgaria. Final report on the National Grasslands Inventory Project - Bulgaria, 2001-2004. Dragon 2003 Ltd. Publishers, Sofia, $104 \mathrm{pp}$.

Mihăilescu, S. 2001: The flora and vegetation of 
Piatra Craiuliu massif. Vergiliu, Bucharest, 400 pp. (in Romanian).

Mišić, V. 1960: Results from ecological study of subalpine shrub vegetation of Kopaonik Mountain. Biol. Inst. N. R. Srbije, Posebna izdanja. Belgrade 6: 5-47 (in Serbian).

Mišić, V., Jovanović-Dunjić, R., Popović, M., Borisavljević, L., Antić, M., Dinić, A., Danon, J. \& Blaženčić, Ž. 1978: Plant communities and habitats of the Stara Planina Mountains. Belgrade, 389 pp. (in Serbian).

Mucina, L., Valachovič, M., Jarolimek, I., Šeffer, J., Kubinská, A. \& Pišut, I. 1990: The vegetation of rock fissures, screes and snow-beds in the Pirin Planina Mt. (Bulgaria). - Studia Geobot. 10: 15-58.

Mueller-Dombois, D. \& Ellenberg, H. 1974: Aims and Methods of Vegetation Ecology. John Wiley \& Sons, Inc., New York, 547 pp.

Natcheva, R. \& Ganeva, A. 2005. Check-list of the bryophytes of Bulgaria. II. Musci. Cryptogami, Bryol. 26(2): 209-232.

Niculescu, M. 2004: Contributions regarding the study of the Nardo-Callunetea Prsg. 1949 class in the upper basin of Luncavat river (Valcea County). Contrib. Bot. 39: 89-93.

Oberdorfer, E. 1994: Pflanzensoziologische Excursionsflora. Verlag Eugen Ulmer, Stuttgart, $1050 \mathrm{pp}$.

Obratov-Petković, D., Popović, I., \& Dajić-Stevanović, Z. 2007: Diversity of the vascular flora of Mt. Zlatar (Southwest Serbia). - EurAsia J. Bio. Sci. 1(5): 35-47.

Pavlović, Z. 1951: The vegetation of Zlatibor Mountain. - Zborn. Rad. Inst. za ekol. i biogeog. SAN Belgrade 2: 115-178 (in Serbian).

Petrík, A., Šibík, J. \& Valachovič, M. 2005: The Class Carici rupestris - Kobresietea bellardii Ohba 1974 also in the Western Carpathians. Hacquetia 4(1): 33-51.

Petrov, I. \& Mesaroš, G. 1988: Contribution to Myrmecofauna of the mountain Stara planina. Biosistematika 14(1): 43-50.

Pop, I., Cristea, V., Hodişan, I. \& Gergely, I. 1988: Le Conspectus des associations végétales sur l'étendue du départment de Cluj. Contrib. Bot. 28: 10-23.

Pop, I., Cristea, V. \& Hodişan, I. 2002: The Vegetation of Cluj District (a phytocoenological, ecological, bioeconomic and ecoprotective study). Contrib. Bot. 35(2): 5-254 (in Romanian).

Pop, V. 1997: Earthworm - vegetation - soil rela- tionships in the Romanian Carpathians. - Soil Biol. Biochem. 29(3/4): 223-229.

Prots, B., Kruglov, I., Bashta, A.-T. \& Tasenkevich, L. 2008: Report on the results of data collection for Ukrainian Carpathian Mts. and encountered problems. BBI-MATRA project. - http://www.carpates.org/docs/2008/cbis08/ Report_Ukraine.pdf (accessed 22.04.2008).

Puşcaru, D., Puşcaru - Soroceanu, E., Paucă, A., Şerbănescu, I., Beldie, Al., Ştefureac, T., Cernescu, N., Saghin, F., Crețu, V., Lupan, L. \& Taşcenco, V. 1956: Alpine pastures of Bucegi Mountain. Acad. Press, Bucharest, 511 pp. (in Romanian).

Puzović, S., Stojnić, N., Lazarević, P., Butorac B., Sekulić, G., Mijović, D., Vukelić M., Radosavljević \& Čalakić, D. 2006: Information Sheet on Ramsar Wetlands. http://www.wetlands.org/reports/ris/3RS006_RIS2006.pdf (accessed 20.05.2008).

Resmeriță, I. 1970: Flora, vegetation and productivity potential of the Vlădeasa massif. Acad. Press, Bucharest, 318 pp. (in Romanian).

Resmeriță, I. 1986: Associations Potentillo (ternatae - aureae) - Festucetum supinae Boşcaiu 1971 and Potentillo (ternatae - aureae) - Festucetum ovinae Resmeriță 1970 in Romanian Carpathians. Contrib. Bot. 26: 184-188 (in Romanian).

Resmeriță, I. \& Csűrös, Ş. 1966: Geobotanical and agrotechnical mapping of Cionca pasture (region Huedin). Contrib. Bot. 2: 91-102 (in Romanian).

Rodwell, J., Schamineé, J., Mucina, L., Pignatti, S., Dring, J., \& Moss, D. 2002: The diversity of European vegetation - An overview of phytosociological alliances and their relationships to EUNIS habitats. Wageningen, $168 \mathrm{pp}$.

Roussakova, V. 2000: Végétation alpine et sous alpine supérieure de la montagne de Rila (Bulgarie). Braun-Blanquetia 25: 1-132.

Sanda, V., Popescu, A. \& Peicea, I. M. 1988: Les associations de buissons subalpins des Carpates de Roumanie. Contrib. Bot. 28: 85-95.

Sanda, V., Popescu, A. \& Barabaş, N. 1997: Syntaxonomy and characteristics of Romanian vegetation. Bacau, 366 pp. (in Romanian).

Sanda, V., Alexiu, V. \& Şincu, E. D. 2006: Alpine pastures and mountain ruderal vegetation in Bucegi Mountain. Ecos 18: 27-32 (in Romanian).

Sarbu, A., Coldea, G., Negrean, G., Cristea, V., Hanganu, J. \& Veen, P. 2004: Grasslands of Romania. Final report on National Grasslands 
Inventory 2000-2003. Univ. of Bucharest, $7 \mathrm{pp}$.

Simon, T. 1958: Über die alpinen pflanzengesellsschaften des Pirin-Gebirges. Acta Bot. Acad. Sci. Hung. 4(1-2): 159-190.

Simon, T. 1966: Beitrage zur Kenntnis der vegetation des Bihar (Bihor) Gebirges. - Ann. Univ. Sci. Budapestensis. Sect. Biologica 8: 253-273.

Tichý, L. 2002: JUICE, software for vegetation classification. J. Veg. Sci. 13: 451-453.

Velchev, V. 1984: Vegetational belts in the mountains of Bulgaria. In: Velchev, V. (ed.): Contemporary theoretical and practical aspects of vegetation ecology, Vol. 1, 67-76 pp. (in Bulgarian).

Velchev, V. 2002: Characteristic features and regularities in the distribution of the present-day vegetation. In: Kopralev, I. (ed.): Geography of Bulgaria, FarCom, Sofia, 321-324 pp. (in Bulgarian).

Velchev, V., Bondev, I., Kochev, H., Roussakova, V., Vasilev, P., Meshinev, T., Nikolov, V, Georgiev, N. \& Valchev, V. 1989: Vegetation. In: Mi- shev, K. (ed.): Natural and Economic Potential of the Mountains in Bulgaria. Nature and Resources. Vol. 1, Publ. House of the Bulg. Acad.Sci., Sofia, 273-337 pp. (in Bulgarian).

Velev, N. \& Apostolova, I. 2008: Successional changes of Nardus stricta communities in the Central Balkan Range (Bulgaria). Phytol. Balcan. 14(1): 65-74.

Weber, H., Moravec, J. \& Theurillat, J.-P. 2000: International Code of Phytosociological Nomenclature. $3^{\text {rd }}$ ed. J. Veg. Sci. 11: 739-768.

Westhoff, V. \& van der Maarel, E. 1973: The Braun-Blanquet Approach. In: Whittaker, R. (ed.), Ordination and Classification of Communties. Handbook of Vegetation Science Vol. 5. Junk, The Hague, 617-726 pp.

Wirth, V. 1995: Die Flechten Baden-Württembergs. Teil 1 \& 2. Eugen Ulmer GmbH \& Co., Stuttgart, $1006 \mathrm{pp}$.

Witkowski, Z., Król, W. \& Solarz, W. (eds.): 2003. Carpathian List of Endangered Species. WWF and Institute of Nature Conservation, Polish Academy of Sciences, Vienna-Krakow, 64 pp. 
Table 1: Associations Nardetum strictae Greb. 1950 and Campanulo alpinae - Nardetum strictae (Simon 1958) nom. nov.

\begin{tabular}{|c|c|}
\hline \multirow[b]{2}{*}{ Locality } & Nardetum strictae \\
\hline & Balkan Mountain \\
\hline Relevé number & $\begin{array}{lllllllllllllllllllllllllllll}1 & 2 & 3 & 4 & 5 & 6 & 7 & 8 & 9 & 10 & 11 & 12 & 13 & 14 & 15 & 16 & 17 & 18 & 19 & 20 & 21 & 22 & 23 & 24 & 25 & 26 & 27 & 28 & 29\end{array}$ \\
\hline Altitude (m) & 号员员 \\
\hline Exposition & 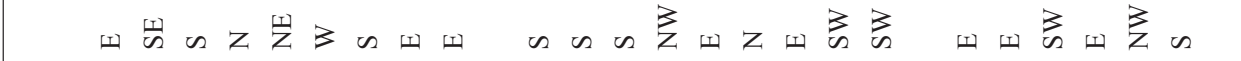 \\
\hline
\end{tabular}

Potentillo ternatae - Nardion strictae

Nardus stricta *

Bruckenthalia spiculifolia

Hieracium hoppeanum

Hypericum maculatum

Potentilla erecta

Potentilla ternata *

Geum montanum

Antennaria dioica

Bellardiochloa violacea

Thymus vandasii

Alchemilla flabellata

Viola dacica

Luzula sudetica

Festuca nigrescens

Homogyne alpina *

Campanula patula ssp.

abietina

Ligusticum mutellina

Campanula rotundifolia

Scorzonera purpurea ssp.

rosea

Carex ovalis

Veronica officinalis

Plantago atrata

Plantago gentianoides

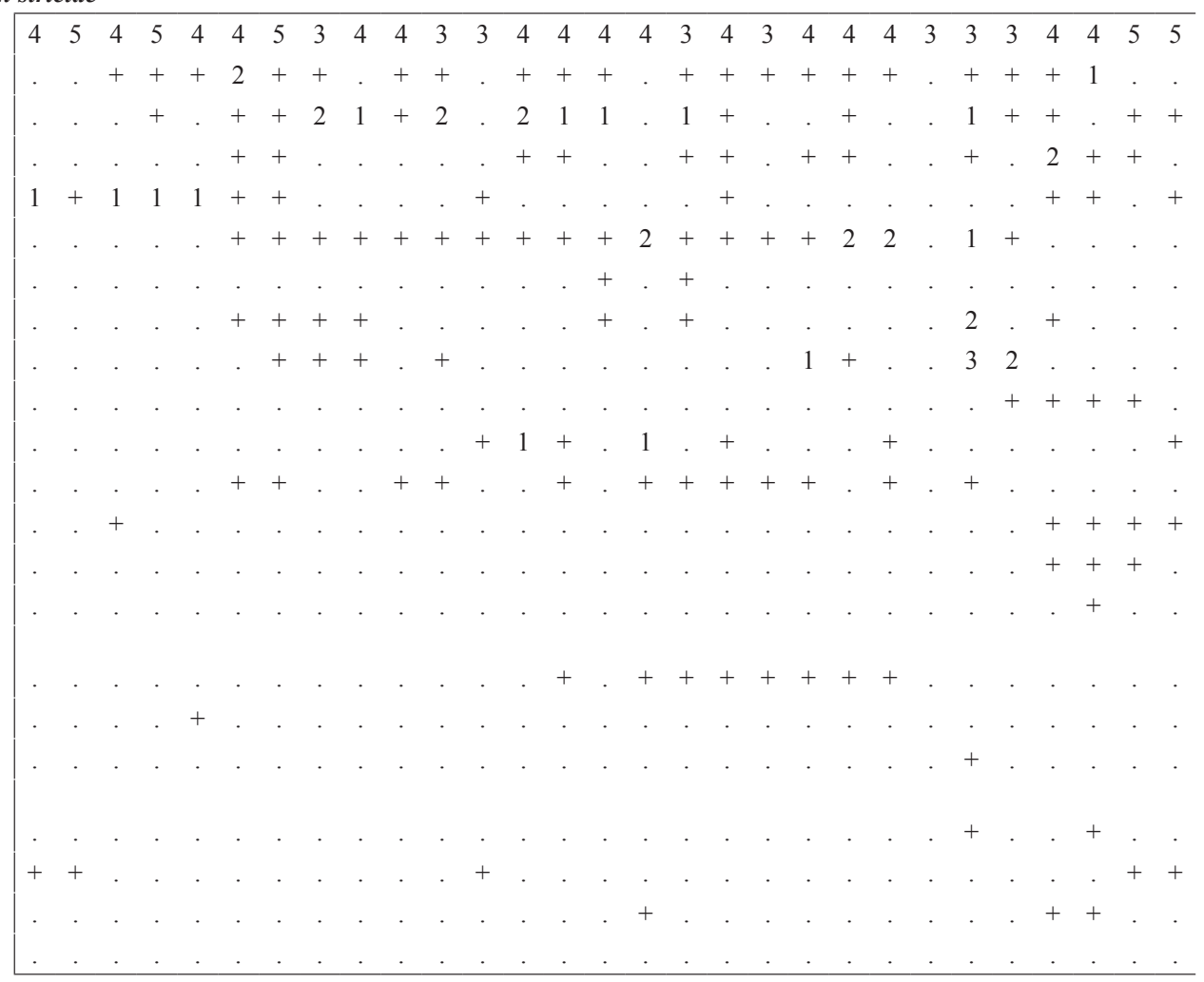

Nardetalia strictae and Nardo - Callunetea

Agrostis capillaris

Festuca rubra

Vaccinium myrtillus

Lerchenfeldia flexuosa

Anthoxanthum odoratum

Vaccinium vitis-idaea

Chamaespartium sagittale

Luzula multiflora

Rumex acetosella

Hieracium pilosella

Sieglingia decumbens

Hypericum perforatum

Ranunculus acris

Luzula campestris

\begin{tabular}{|c|c|c|c|c|c|c|c|c|c|c|c|c|c|c|c|c|c|c|c|c|c|c|c|c|c|c|c|c|}
\hline 2 & 1 & + & + & 2 & 1 & 1 & 2 & 1 & + & 1 & + & 2 & 2 & 2 & 2 & 3 & 3 & 2 & 2 & 3 & 2 & 3 & 2 & + & 3 & 2 & 2 & 2 \\
\hline 2 & 1 & 1 & + & 2 & 1 & 1 & + & . & 1 & 1 & 2 & 2 & 2 & 1 & 3 & 2 & 2 & 3 & 2 & 2 & 2 & $v^{\circ}$ & 3 & 3 & $\cdot$ & . & + & + \\
\hline . & . & . & + & + & 1 & + & + & . & + & & . & + & 1 & + & . & + & + & 1 & 1 & + & + & . & 2 & + & + & 2 & + & + \\
\hline . & . & . & + & . & + & 1 & + & . & + & & . & . & . & + & . & + & 2 & 2 & + & . & + & . & 2 & 2 & + & 1 & + & + \\
\hline$\cdot$ & . & . & . & . & 1 & + & + & + & + & + & . & . & . & $\cdot$ & . & . & + & + & 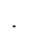 & . & . & . & + & + & + & + & + & . \\
\hline . & . & . & + & + & + & + & + & . & . & & . & + & + & + & . & 1 & + & + & + & + & + & . & + & $\cdot$ & . & 1 & 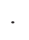 & + \\
\hline$\cdot$ & . & . & . & . & + & + & + & . & + & + & . & . & . & . & + & . & 1 & + & . & + & + & . & $\cdot$ & $\cdot$ & $\cdot$ & 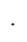 & $\cdot$ & . \\
\hline 1 & . & . & . & + & . & . & . & . & . & & . & . & + & + & + & + & + & 1 & + & + & . & . & 2 & + & $\cdot$ & $\cdot$ & $\cdot$ & . \\
\hline$\cdot$ & . & . & . & $\cdot$ & + & + & + & $\cdot$ & + & 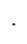 & + & $\cdot$ & $\cdot$ & 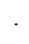 & . & + & ${ }^{\circ}$ & . & + & + & $\cdot$ & . & . & + & . & + & $\cdot$ & . \\
\hline . & $\cdot$ & . & $\cdot$ & $\cdot$ & $\cdot$ & $\cdot$ & . & $\cdot$ & . & & & $\cdot$ & $\cdot$ & $\cdot$ & $\cdot$ & 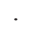 & . & . & 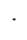 & $\cdot$ & $\cdot$ & . & $\cdot$ & $\cdot$ & . & + & $\cdot$ & . \\
\hline . & + & . & . & . & . & + & 1 & + & + & + & . & $\cdot$ & $\cdot$ & $\cdot$ & $\cdot$ & 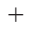 & $\cdot$ & $\cdot$ & $\cdot$ & . & $\cdot$ & $\cdot$ & $\cdot$ & $\cdot$ & $\cdot$ & $\cdot$ & $\cdot$ & + \\
\hline • & . & $\cdot$ & $\cdot$ & $\cdot$ & 1 & + & + & . & $\cdot$ & + & $\cdot$ & $\cdot$ & $\cdot$ & $\cdot$ & $\cdot$ & $\cdot$ & $\cdot$ & $\cdot$ & $\cdot$ & $\cdot$ & $\cdot$ & $\cdot$ & $\cdot$ & $\cdot$ & $\cdot$ & $\cdot$ & $\cdot$ & . \\
\hline+ & + & . & $\cdot$ & + & $\cdot$ & . & $\cdot$ & $\cdot$ & . & 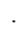 & $\cdot$ & $\cdot$ & $\cdot$ & $\cdot$ & $\cdot$ & $\cdot$ & $\cdot$ & $\cdot$ & $\cdot$ & · & $\cdot$ & $\cdot$ & $\cdot$ & $\cdot$ & $\cdot$ & $\cdot$ & . & . \\
\hline & . & . & . & . & . & . & . & . & . & . & $\cdot$ & . & . & . & . & . & . & . & . & . & . & . & $\cdot$ & . & . & . & . & . \\
\hline
\end{tabular}


Tabela 1: Asociaciji Nardetum strictae Greb. 1950 in Campanulo alpinae - Nardetum strictae (Simon 1958) nom. nov.

\begin{tabular}{|c|c|c|c|c|c|}
\hline \multirow{2}{*}{\multicolumn{2}{|c|}{$\begin{array}{c}\text { Nardetum strictae } \\
\text { Balkan Mountain }\end{array}$}} & \multicolumn{4}{|c|}{ Campanulo alpinae - Nardetum strictae } \\
\hline & & Mt. Pirin & & Mt. Balkan & \\
\hline $\begin{array}{llllllllllllllllllllll}30 & 31 & 32 & 33 & 34 & 35 & 36 & 37 & 38 & 39 & 40 & 41 & 42 & 43 & 44 & 45 & 46 & 47 & 48 & 49 & 50 & 51\end{array}$ & & $\begin{array}{llllll}52 & 53 & 54 & 55 & 56 & 57\end{array}$ & & $\begin{array}{lllll}58 & 59 & 60 & 61 & 62\end{array}$ & \\
\hline 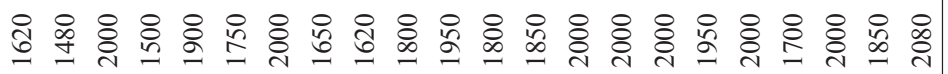 & 恖 & 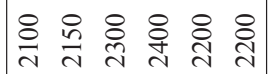 & 总 & 号点 & 产 \\
\hline 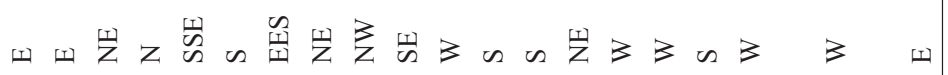 & o & is a & u & 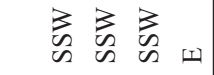 & 0 \\
\hline
\end{tabular}
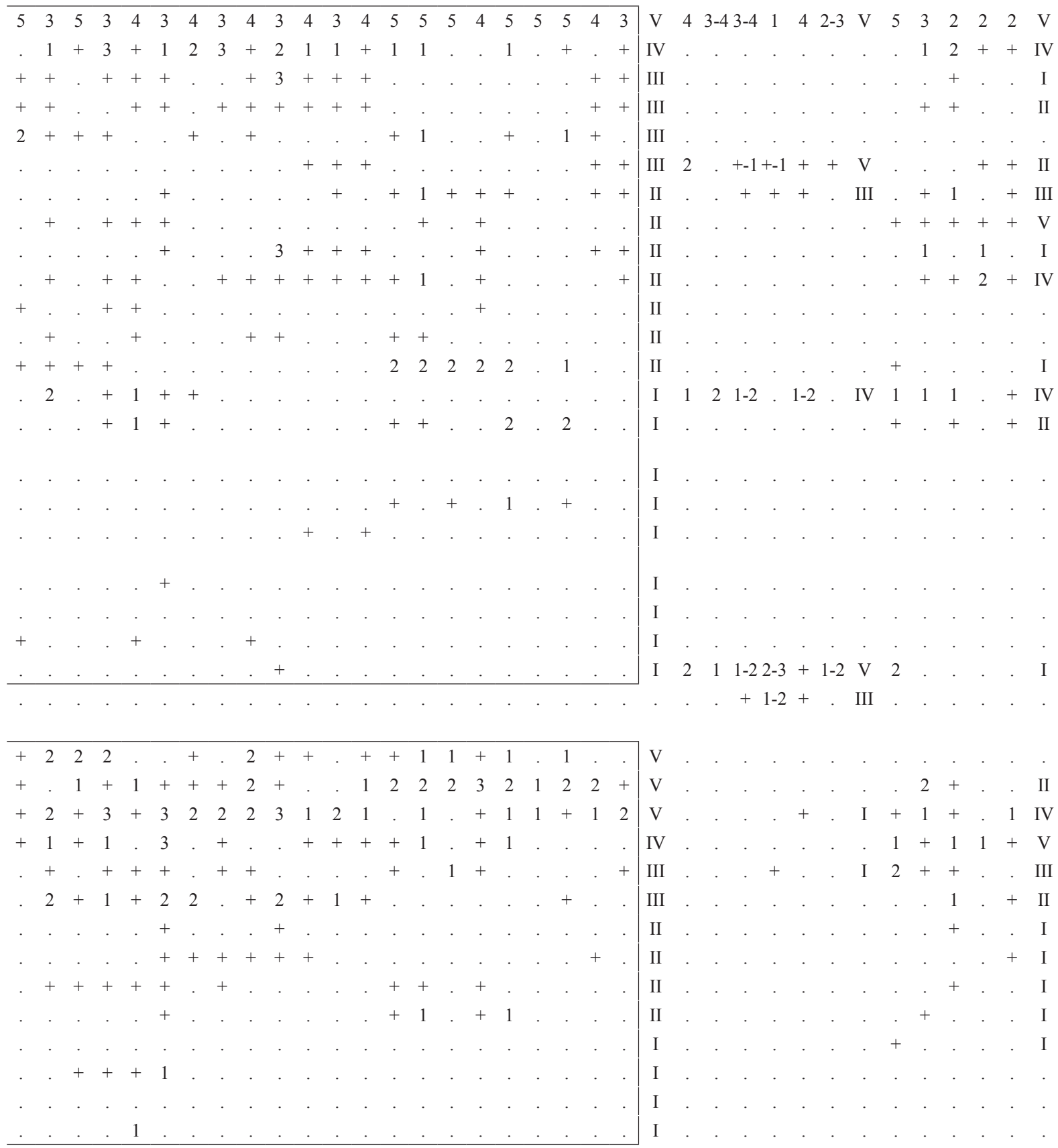
Relevé number

Seslerion comosae

Campanula alpina

Juncus trifidus

Agrostis rupestris

Dianthus microlepis

Cetraria islandica

Festuca airoides

Veronica bellidioides

Omalotheca supina

Euphrasia minima

Hieracium alpicola gr.

Sesleria comosa

Seslerietalia comosae and Juncetea trifidi

Poa media

Scleranthus neglectus

Ranunculus montanus

Alopecurus gerardii

Carex kitaibeliana

Crocus veluchensis

Luzula italica

Festuca riloensis

Other species

Juniperus sibirica

Vaccinium uliginosum

Carex caryophyllea

Genista depressa s.1.

Campanula patula ssp. epigaea

Verbascum longifolium

Luzula luzuloides

Acinos alpinus

Potentilla crantzii

Trifolium repens s.1.

Gentianella bulgarica

Agrostis canina

Arenaria biflora

Bistorta major

Thymus zygioides

Trifolium pratense

Veronica chamaedrys

Thymus jankae

Peucedanum oligophyllum

Campanula velebitica

Cruciata glabra

Hieracium sparsum

Koeleria eriostachya

Geum coccineum

Luzula pindica

Omalotheca sylvatica

Plantago subulata

Polytrichum juniperinum

Potentilla haynaldiana

Veratrum lobelianum

Sagina saginoides 


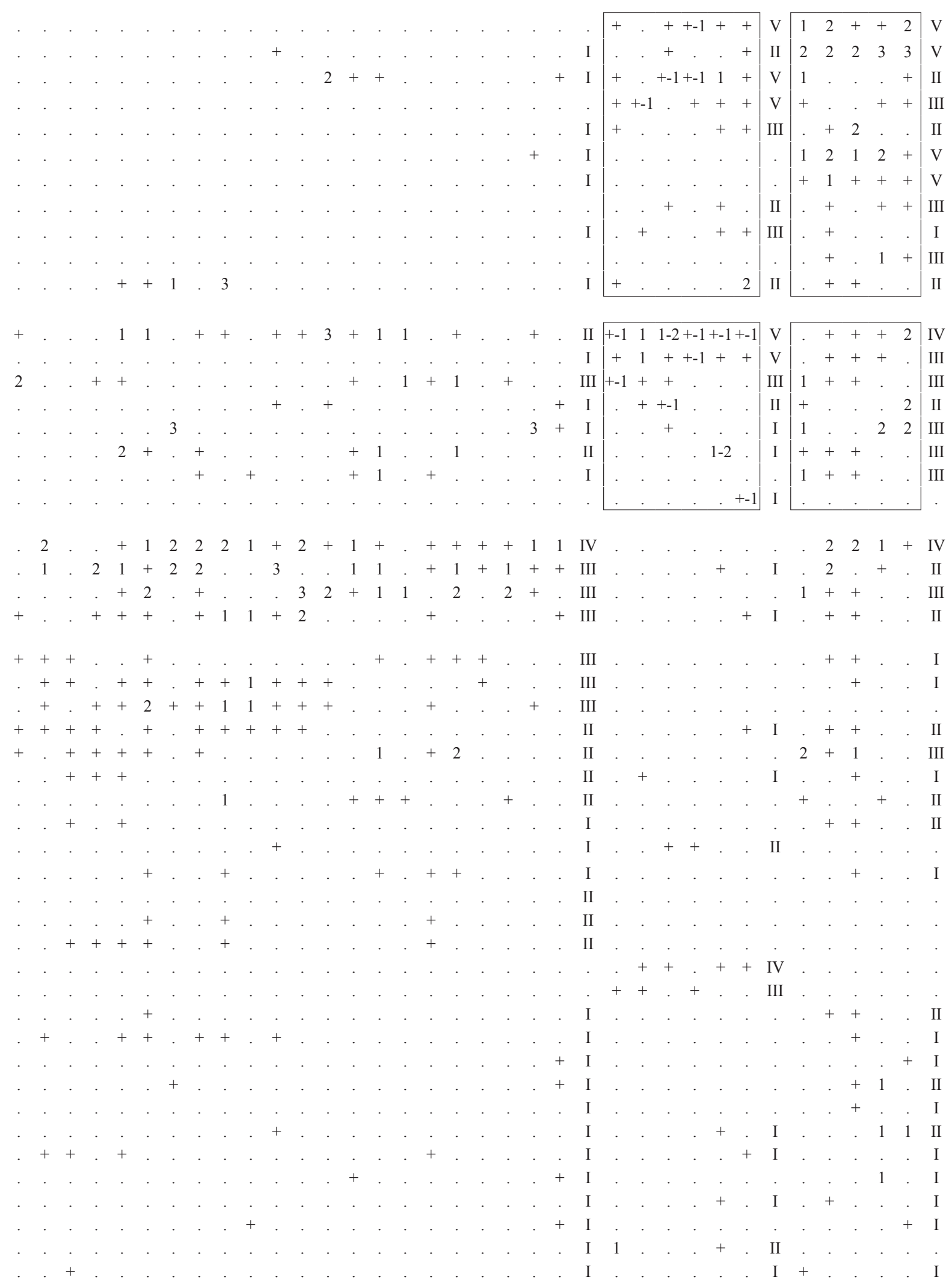


Relevé number $\begin{array}{lllllllllllllllllllllllllllll}1 & 2 & 3 & 4 & 5 & 6 & 7 & 8 & 9 & 10 & 11 & 12 & 13 & 14 & 15 & 16 & 17 & 18 & 19 & 20 & 21 & 22 & 23 & 24 & 25 & 26 & 27 & 28 & 29\end{array}$

Stellaria graminea

Achillea millefolium

Alchemilla vulgaris agg.

Calamagrostis arundinacea

Campanula sparsa

Carduus carduelis

Centaurea napulifera

Cerastium arvense

Cerastium banaticum

Chamaecytisus pygmaeus

Cruciata laevipes

Deschampsia caespitosa

Euphrasia liburnica

Festuca valida

Helianthemum nummularium

Juncus conglomeratus

Leontodon autumnalis s.1.

Leontodon hispidus

Lotus corniculatus

Omalotheca norvegica

Plantago lanceolata

Poa апnиа

Potentilla argentea

Rubus idaeus

Satureja montana

Scleranthus perennis

Senecio abrotanifolius

Thlaspi kovatsii

Viola tricolor

Picea abies

Pinus mugo

Polytrichum piliferum

Rhizocarpon alpicola

Caloplaca sinapisperma

Cladonia pyxidata

Lepraria neglecta

Bryum sp.

Taraxacum sp.

* Species mentioned in the literature as diagnostic also for order Seslerietalia comosae and class Juncetea trifidi. 


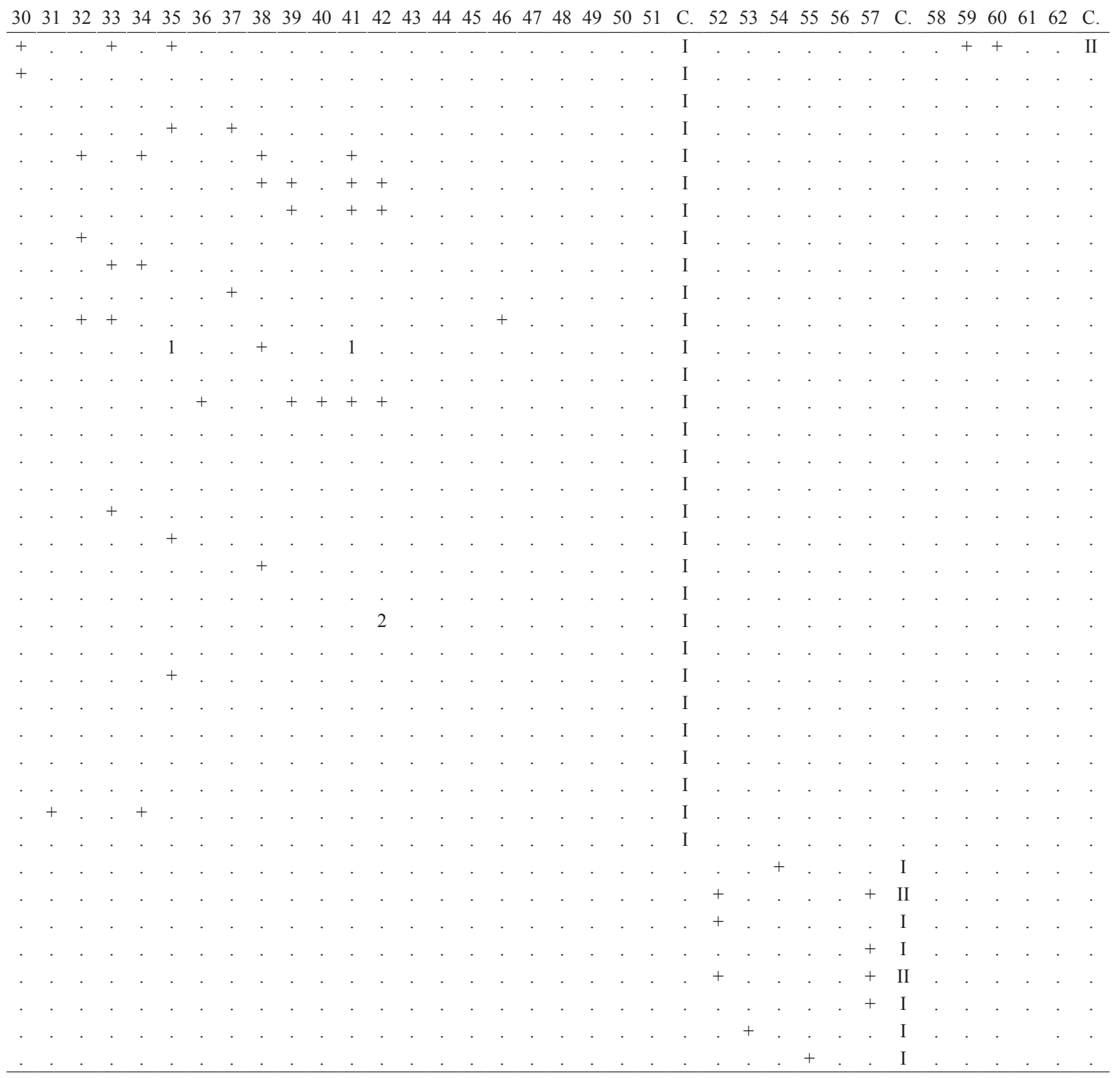


Table 2: Altitudinal range of some Potentillo ternatae - Nardion strictae syntaxa.

Table 2: Razpon nadmorskih višin nekaterih sintaksonov zveze Potentillo ternatae - Nardion strictae.

\begin{tabular}{|c|c|c|c|}
\hline Syntaxon & Altitudinal range & Country & Reference \\
\hline Nardetum alpinum moesiacum & $2100-2400 \mathrm{~m}$ & Bulgaria & Simon 1958 \\
\hline Carici-Festucetum microphyllae & $2170-2200 \mathrm{~m}$ & Bulgaria & Roussakova 2000 \\
\hline Poa media dominated communities & $2160-2700 \mathrm{~m}$ & Bulgaria & Roussakova 2000 \\
\hline \multirow[t]{2}{*}{ Nardetum strictae } & \multirow[t]{2}{*}{$1000-2080 \mathrm{~m}$} & FFRY * & $\begin{array}{l}\text { Pavlović 1951; Mišić 1960; Mišić et al. } \\
\text { 1978; Petrov \& Mesaroš } 1988\end{array}$ \\
\hline & & Bulgaria & Velev \& Apostolova 2008 \\
\hline Hygronardetum strictae & $1370-1700 \mathrm{~m}$ & FFRY & Mišić et al. 1978 \\
\hline Helianthemo - Nardetum strictae & $1700-1900 \mathrm{~m}$ & FFRY & Janković 1982 \\
\hline Festuco fallaci-Nardetum strictae & $500-1800 \mathrm{~m}$ & FFRY & Janković 1982 \\
\hline Festuco halleri-Nardetum strictae & $2000-2300 \mathrm{~m}$ & FFRY & Janković 1982 \\
\hline \multirow{5}{*}{ Violo declinatae - Nardetum strictae } & \multirow{5}{*}{$570-2200 \mathrm{~m}$} & \multirow{5}{*}{ Romania } & $\begin{array}{l}\text { Puşcaru et al. 1956; Borza 1959; Simon } \\
\text { 1966; Beldie 1967; } 2006\end{array}$ \\
\hline & & & $\begin{array}{l}\text { Coldea 1987; Resmeriță 1970; Pop et al. } \\
\text { 2002; Grigoriu \& Alda } 2004\end{array}$ \\
\hline & & & $\begin{array}{l}\text { Niculescu 2004; Sarbu 2004; Sanda et al. } \\
\text { 2006; Chifu et al. } 2006\end{array}$ \\
\hline & & & $\begin{array}{l}\text { Puşcaru et al. 1956; Csürös \& Resmeriță } \\
\text { 1960; Gergely } 1969\end{array}$ \\
\hline & & & $\begin{array}{l}\text { Coldea 1987, 1990; Coldea \& Pop 1988; } \\
\text { Mihăilescu } 2001\end{array}$ \\
\hline \multirow[t]{2}{*}{ Scorzonero roseae - Festucetum nigricantis } & \multirow[t]{2}{*}{$850-1950 \mathrm{~m}$} & \multirow[t]{2}{*}{ Romania } & $\begin{array}{l}\text { Pop et al. 2002; Niculescu 2004; Sarbu } \\
\text { 2004; Sanda et al. } 2006\end{array}$ \\
\hline & & & Chifu et al. 2006 \\
\hline Campanulo serratae - Festucetum ovinae & $1100-2120 \mathrm{~m}$ & Romania & $\begin{array}{l}\text { Resmeriță 1986; Coldea 1987; Pop et al. } \\
2002\end{array}$ \\
\hline Hieracio polosellae - Nardetum strictae & $700-1250 \mathrm{~m}$ & Romania & Resmeriță 1970; Pop et al. 2002 \\
\hline \multirow[t]{2}{*}{ Carici-Nardetum strictae } & \multirow[t]{2}{*}{$1100-1850 \mathrm{~m}$} & \multirow[t]{2}{*}{ Romania } & $\begin{array}{l}\text { Puşcaru et al. 1956; Buia 1963; Beldie } \\
\text { 1967; Resmeriţă } 1970\end{array}$ \\
\hline & & & Pop et al. 2002 \\
\hline Nardo-Callunetum vulgaris & $800-1600 \mathrm{~m}$ & Romania & $\begin{array}{l}\text { Ghişa et al. 1970; Resmeriță 1970; Pop } \\
\text { et al. } 2002\end{array}$ \\
\hline Poetum mediae & $1700-2020 \mathrm{~m}$ & Romania & $\begin{array}{l}\text { Coldea 1990; Niculescu 2004; Sarbu } \\
\text { 2004; Donițã } 2005\end{array}$ \\
\hline Antennario - Festucetum sudeticae & $1550-2150 \mathrm{~m}$ & Romania & Boşcaiu 1971 \\
\hline Soldanello-Nardetum & $1200-1750 \mathrm{~m}$ & Ukraine & Malinovsky \& Kricsfalusy 2000 \\
\hline
\end{tabular}

* FFRY - Former Federal Republic of Yugoslavia 